\title{
Stakeholder Engagement Sebagai Praktik CSR dan Pengungkapannya Pada Kelompok Usaha Lippo Group
}

\author{
Stefani Christina Kurnia Dewi ${ }^{1}{ }^{*}$, Arthik Davianti ${ }^{2}$ \\ 1,2 Departemen Akuntansi, Fakultas Ekonomika \& Bisnis Universitas Kristen Satya Wacana (UKSW) Salatiga
}

\section{A R T I C L E I N F O}

Article history:

Received 19 August 2019

Received in revised form

16 September 2019

Accepted 15 October 2019

Available online 30

November 2019

\section{Kata Kunci:}

CSR, perusahaan afiliasi pengungkapan, stakeholder engagement

Keywords: CSR, affiliated companies, disclosures, stakeholder engagement

\begin{abstract}
A B S T R A K
Hubungan perusahaan dengan para stakeholder-nya merupakan bagian penting dari proses CSR, sehingga pengungkapan tentang pokok stakeholder engagement ini juga merupakan bagian penting dari pengungkapan CSR perusahaan. Tujuan dari penelitian ini adalah untuk mendapatkan bukti empiris tentang pokok stakeholder engagement yang meliputi pemasok, pelanggan, tenaga kerja dan kelompok stakeholder lainnya disajikan dalam pengungkapan CSR perusahaan afiliasi Lippo Group. Penelitian dilakukan terhadap dua belas anak perusahaan Lippo Group yang terdaftar di Bursa Efek Indonesia periode tahun 2018. Metode analisis isi digunakan dengan mengacu pada laporan tahunan perusahaan yang diteliti di dalam kelompok usaha Lippo Group. Hasil analisis menunjukkan bahwa pokok-pokok stakeholder engagement secara keseluruhan telah diungkapkan dalam laporan tahunan perusahaan yang diteliti, dan pokok-pokok tersebut diketahui cukup berperan penting dalam keberlangsungan suatu perusahaan dan dalam pengungkapan CSR perusahaan.
\end{abstract}

\section{A B S T R A C T}

The company's relationship with their stakeholders is an important part of the CSR process, so the disclosure of the principal stakeholder engagement is also an important part of the company's CSR disclosure. The purpose of this study is to obtain empirical evidence about the principal stakeholder engagement which includes suppliers, customers, labor and other stakeholder groups is presented in CSR disclosures of affiliated companies of Lippo Group. The study was conducted on twelve Lippo Group subsidiaries listed on the Indonesia Stock Exchange in the period of 2018. The content analysis method is used by referring to the annual reports of the companies studied in the Lippo Group business. The results of the analysis indicate that the overall stakeholder engagement have been disclosed in the annual report of the company which has been studied, and these points are known to have an important role in the sustainability of a company and in the disclosure of corporate CSR.

\footnotetext{
* Corresponding author.

E-mail addresses: arthik.davianti@uksw.edu (Arthik Davianti)
} 


\section{Pendahuluan}

Pada era sekarang ini, tanggung jawab perusahaan dapat berupa tanggung jawab sosial, tanggung jawab lingkungan, dan tanggung jawab finansial. Tanggung jawab tersebut kemudian dikomunikasikan oleh perusahaan kepada stakeholder melalui pengungkapan Corporate Social Responsibility (CSR) yang ditujukan kepada para stakeholder. Stakeholder yang dimaksud adalah pihak-pihak lain diluar perusahaan seperti pemerintah, lingkungan, Lembaga Swadaya Masyarakat, dan para pekerja. Menurut Lindawati \& Puspita (2015) pengungkapan CSR juga menjadi sinyal yang diberikan pihak manajemen kepada seluruh

stakeholder termasuk calon investor mengenai prospek perusahaan dimasa yang akan datang.

Dasar hukum CSR tertuang dalam UU No.40 Tahun 2007 tentang Perseroan Terbatas (PT) pasal 74

UU RI Ayat 1 mengenai Tanggung Jawab Sosial dan Lingkungan, yaitu: Perseroan yang menjalankan kegiatan usahanya di bidang dan atau berkaitan dengan sumber daya alam wajib melaksanakan tanggung jawab sosial dan lingkungan. Jika dikaitkan dengan stakeholder oriented dapat dicermati di dalam UUPT pasal 1 angka 3 dinyatakan bahwa tanggung jawab sosial dan lingkungan adalah komitmen Perseroan untuk berperan serta dalam pembangunan ekonomi berkelanjutan guna meningkatkan kualitas kehidupan dan lingkungan yang bermanfaat, baik bagi Perseroan sendiri, komunitas setempat, maupun masyarakat pada umumnya (Undang-undang Republik Indonesia, 2007).

Menurut Global Reporting Initiative (2016), Standar 101 tentang Landasan, stakeholder didefinisikan sebagai entitas atau individu yang diperkirakan akan terpengaruh oleh kegiatan, produk, atau jasa organisasi pelapor, atau yang tindakannya diperkirakan akan mempengaruhi kemampuan organisasi dalam menerapkan strategi atau mencapai tujuannya. Lebih lanjut, kriteria kepuasan stakeholder berbeda-beda pada setiap perusahaan (Certo \& Certo, 2006). Penekanan yang berlebihan pada kebutuhan satu kelompok stakeholders dapat memberikan penilaian negatif terhadap reputasi perusahaan (Lindgreen, Swaen, \& Johnston, 2009). Menurut Harrison dan St. John stakeholder yang salah satunya termasuk masyarakat dapat memberikan dampak terhadap citra dan reputasi perusahaan yang akan berdampak pada pendapatan perusahaan (dalam Lindawati \& Puspita, 2015). Oleh sebab itu, peningkatan nilai reputasi perusahaan dapat terwujud apabila perusahaan dapat menyesuaikan diri terhadap kepentingan stakeholder-nya (Dickinson-Delaporte et all, 2010).

Penelitian Rowley \& Berman (2000) menunjukkan bahwa stakeholder memiliki pengaruh terhadap hubungan pengungkapan CSR dan harga saham. Sementara itu, penelitian yang dilakukan oleh Mishra \& Suar (2010) mengatakan bahwa kebijakan perusahaan yang memperhitungkan faktor kesehatan konsumen dan keamanan penggunaan produk dapat meningkatkan citra dan kinerja perusahaan. Selain itu, Lindawati \& Puspita (2015) menunjukan bukti bahwa pengungkapan CSR yang dilakukan oleh perusahaan akan membuat stakeholder memberikan dukungan penuh kepada perusahaan atas segala aktivitasnya. Sedangkan penelitian yang dilakukan Trisnawati (2014) menghasilkan ukuran dewan komisaris, sebagai stakeholder internal, tidak berpengaruh terhadap pengungkapan CSR. Hasil penelitianpenelitian tersebut menunjukkan hubungan antara stakeholder dan pengungkapan CSR yang disajikan perusahaan. Perusahaan sendiri dapat dalam bentuk perusahaan publik, maupun perusahaan privat, termasuk konglomerasi dalam bentuk kelompok bisnis dalam perusahaan yang saling berafiliasi.

Penelitian ini berfokus pada suatu perusahaan afiliasi yaitu Lippo Group. Lippo Group didirikan oleh Dr. Mochtar Riady sejak tahun 1958 dengan berbagai jenis usaha ini di bidang jasa seperti properti, ritel, pendidikan, kesehatan, teknologi, telekomunikasi, multimedia, dan keuangan. Lippo Group ini memiliki lebih dari 50 anak perusahaan dan aktivitas bisnisnya tidak hanya dilakukan di Indonesia melainkan sampai di luar negri. Saat ini Lippo Group paling tidak memiliki lima area bisnis utama. Lippo Group juga merupakan salah satu perusahaan konglomerasi dengan adanya peran stakeholder perusahaan yang lama kelamaan akan cukup berperan besar terhadap perkembangan perusahaan juga.

Selain itu, Lippo Group dikenal juga sebagai perusahaan yang mampu memanfaatkan dengan baik pasar modal dalam dan luar negeri sebagai sumber pendanaannya (Dorimulu, 2016). Perhatian pada kelompok ini pada kasus Meikarta, yang merupakan megaproyek properti yang dikerjakan oleh PT Mahkota Sentosa Utama (MSU) sebagai anak usaha dari PT Lippo Cikarang Tbk (LPCK) yang merupakan salah satu perusahaan bisnis properti dari Lippo Group (Alexander, 2018). Situasi tersebut menyebabkan pengembang proyek Meikarta meyakinkan kepada publik bahwa proyek ini masih terus berjalan (Lamudi, 2019) Isu Meikarta dapat menjadi pokok penting yang dapat memberi nuansa berbeda pada praktik CSR Lippo Group terutama dalam hubungan perusahaan afiliasi dengan para stakeholder.

Berdasarkan penjelasan tersebut, dapat diketahui bahwa stakeholder memiliki hubungan dengan perusahaan dalam menjalankan tanggung jawab sosial. Hubungan Lippo Group dengan para stakeholder merupakan suatu proses CSR yaitu stakeholder engagement. Relasi Lippo Group dengan para stakeholder merupakan bagian penting CSR, sehingga pengungkapan tentang pokok ini juga merupakan bagian pengungkapan CSR yang penting. Pertanyaan penelitian dalam studi ini adalah bagaimana penyajian 
pokok stakeholder engagement dalam pengungkapan CSR? Penelitian ini bertujuan untuk mendapatkan bukti empiris tentang pokok stakeholder engagement yang meliputi pemasok, pelanggan, tenaga kerja dan kelompok stakeholder lainnya disajikan dalam pengungkapan CSR perusahaan afiliasi Lippo Group. Penelitian ini diharapkan dapat menambah bukti empiris atau literatur mengenai keterlibatan stakeholder terhadap praktik pengungkapan CSR.

\section{Metode}

Penelitian ini dilakukan menggunakan pendekatan deskriptif kualitatif. Pendekatan deskriptif kualitatif ini merupakan penelitian yang bertujuan untuk membuat deskripsi mengenai gambaran atau hubungan antara fenomena-fenomena yang diteliti. Dalam penelitian ini dilakukan kegiatan seperti mengumpulkan data, analisis data, interpretasi data, dan diakhiri dengan kesimpulan yang mengacu pada analisis data tersebut. Data yang digunakan dalam penelitian ini merupakan data sekunder. Data sekunder tersebut didapatkan dengan melihat laporan tahunan perusahaan dan/atau sustainability report perusahaan di dalam kelompok usaha Lippo Group yang terdaftar di Bursa Efek Indonesia. Pada penelitian ini, laporan keuangan tahunan yang digunakan sebanyak satu tahun saja yaitu tahun 2018.

Pengumpulan data dilakukan dengan mencari perusahaan dalam satu afiliasi. Salah satu perusahaan yang berafiliasi yaitu Lippo Group. Pada kelompok usaha Lippo Group terdapat kurang lebih 12 anak perusahaan yang terdaftar dalam Bursa Efek Indonesia (BEI), diantaranya sebagai berikut:

Tabel 1Anak Perusahaan Lippo Group yang terdaftar di BEI

\begin{tabular}{llll}
\hline No. & Kode Saham & Nama Perusahaan & Sub Sektor \\
\hline 1. & GMTD & Gowa Makassar Tourism Development Tbk & Property \& Real Estate \\
2. & LPCK & Lippo Cikarang Tbk & Property \& Real Estate \\
3. & LPGI & Lippo General Insurance Tbk & Asuransi \\
4. & LPKR & Lippo Karawaci Tbk & Property \& Real Estate \\
5. & LPLI & Star Pacific Tbk & Advertising, Printing \& Media \\
6. & LPPF & Matahari Department Store Tbk & Perdagangan Eceran \\
7. & LPPS & Lippo Securities Tbk & Keuangan Lainnya \\
8. & MLPL & Multipolar Tbk & Perusahaan Investasi \&Perangkat \\
& & & Jasa Komputer \& \\
9. & MLPT & Multipolar Technology Tbk & Lainnya \\
10. & MPPA & Matahari Putra Prima Tbk & Perdagangan Eceran \\
11. & NOBU & Bank Nationalnobu Tbk & Bank \\
12. & SILO & Siloam International Hospitals Tbk & Kesehatan \\
\hline
\end{tabular}

Teknik analisis yang digunakan yaitu content analysis kualitatif dengan metode deskriptif narasi. Analisis isi deskriptif ini merupakan analisis yang dimaksudkan untuk menggambarkan secara detail suatu teks tertentu (Eriyanto, 2011). Berikut tahapan dari analisis isi tersebut diawali dengan pembuatan lembar coding akan didasarkan pada standar GRI khususnya Standar 102 tentang Pengungkapan Umum mengenai stakeholder engagement. Point-point stakeholder engagement dalam standar GRI adalah seperti survei (survey pemasok, pelanggan, atau pekerja) kelompok fokus, panel komunitas, panel penasihat perusahaan, komunitas tertulis, manajemen atau struktur serikat buruh, perjanjian perundingan kolektif, dan mekanisme lainnya. Point-point tersebut dilihat dari laporan tahunan anak perusahaan Lippo Group yang terdaftar di BEI untuk tahun 2017.

Pokok-pokok stakeholder engagement tersebut dikarenakan beberapa pokok memiliki arti yang sama, maka pada hasil pembahasan dan analisis beberapa pokok ada yang digabungkan. Pokok-pokok yang digabungkan dalam point pelanggan adalah kelompok fokus, panel penasihat perusahaan dan komunitas tertulis. Sedangkan untuk manajemen atau struktur serikat buruh dan perjanjian perundingan kolektif akan digabungkan dengan point tenaga kerja. Selain itu, untuk panel komunitas akan dimasukkan ke dalam point kelompok stakeholder lainnya. Selanjutnya, Proses Coding yang dilakukan atas data-data yang telah dikumpulkan dalam lembar coding. Data tersebut dikumpulkan dalam Excel sheet yang kemudian dipilih berdasarkan penjelasan yang cukup lengkap dalam laporan tahunan perusahaan afiliasi Lippo Group. Terakhir, Input Data dan Analisis yang dilakukan dengan metode deskriptif kualitatif. Input data yang dilakukan berdasarkan pada lembar coding yang telah dibuat. Setelah selesai diinput, baru akan 
dilakukan analisis data tersebut dengan melihat data-data yang telah diambil dan dilihat dari laporan tahunan anak perusahaan Lippo group tersebut. Kemudian berdasarkan hasil analisis yang telah dibuat bisa ditarik kesimpulan.

\section{Hasil dan pembahasan}

Analisis dalam penelitian ini dilakukan dengan mengamati pokok-pokok yang menggambarkan stakeholder engagement pada laporan tahunan perusahaan yang diteliti. Pokok-pokok tersebut telah diklasifikasikan dalam standar GRI. Hal ini bertujuan untuk mendapatkan bukti empiris tentang pokok stakeholder engagement yang meliputi pemasok, pelanggan, tenaga kerja dan kelompok stakeholder lainnya disajikan dalam pengungkapan CSR pada perusahaan yang diteliti. Perbandingan dilakukan pada setiap pokok-pokok tentang stakeholder engagement. Setelah pokok-pokok stakeholder engagement dicari dalam laporan tahunan perusahaan yang diteliti, kemudian akan dibandingkan antara satu perusahaan dengan perusahaan lainnya untuk mengetahui bagaimana pola pelaporan pokok-pokok tersebut. Pada bagian berikut ini menyajikan analisis pada setiap pokok-pokok stakeholder engagement meliputi pengungkapan tentang pemasok, pelanggan, tenaga kerja, dan kelompok stakeholder lainnya.

\section{Pemasok}

Seperti yang sudah diketahui bahwa pemasok atau yang sering dikenal juga dengan supplier atau vendor adalah individu atau perusahaan (baik dalam skala kecil maupun besar) dapat memenuhi kebutuhan individu atau perusahaan lainnya. Pada kedua belas perusahaan yang diteliti, dalam menyeleksi pemasok atau vendor mengacu pada pelaksanaan Good Corporate Governance (GCG) sesuai dengan SEOJK no. 32/POJK.04/2015 pada aspek keempat mengenai Partisipasi Pemangku Kepentingan. Pada peraturan tersebut terdapat rekomendasi mengenai perusahaan terbuka memiliki kebijakan tentang seleksi dan peningkatan kemampuan pemasok atau vendor. Dari dua belas perusahaan yang dianalisis, perusahaan Multipolar Technology Tbk (MLPT) dan Bank Nationalnobu Tbk (NOBU) tidak menjelaskan mengenai pemasok atau vendornya.

Pada sepuluh perusahaan sampel lainnya terdapat delapan perusahaan yang sudah memenuhi atau menerapkan kebijakan mengenai seleksi dan peningkatan kemampuan pemasok atau vendor. Pada perusahaan Gowa Makassar Tourism Development Tbk (GMTD) kebijakan tersebut terdapat dalam kode etik perusahaan. Perusahaan Lippo Cikarang Tbk (LPCK) kebijakan tersebut diungkap dalam bagian Kebijakan dan Seleksi Vendor pada laporan tahunan. Kebijakan dan Seleksi Vendor tersebut tercantum dalam Kode Etik Perusahaan mengenai hubungan dengan pemasok (supplier), vendor (rekanan), termasuk outsourcing dan konsultan. Isi kebijakan tersebut tertera dalam laporan tahunan perusahaan Lippo Cikarang Tbk (LPCK) adalah sebagai berikut:

Evaluasi yang objektif dalam pengadaan perlengkapan dan peralatan Perseroan. Larangan penerimaan kompensasi dari pemasok (supplier), vendor (rekanan termasuk outsourcing), dan konsultan. Kepatuhan pemasok (supplier), vendor (rekanan termasuk outsourcing) dan konsultan terhadap kode etik. Konsultasi dan lobi dengan pemasok (supplier), vendor (rekanan termasuk outsourcing) dan konsultan. (Laporan Tahunan Perusahaan Lippo Cikarang Tbk (LPCK) 2018, hal. 235)

Perusahaan Lippo General Insurance Tbk (LPGI) kebijakan tersebut diatur dalam SOP Departemen General Service tentang Seleksi Supplier/Pemasok dan SOP Departemen Quality Assurance tentang Evaluasi Supplier/Pemasok. Perusahaan Lippo Karawaci Tbk (LPKR) sudah menerapkan kebijakan tersebut. Perusahaan Star Pacific Tbk (LPLI) dan Lippo Securities Tbk (LPPS) menerapkan kebijakan tersebut sesuai dengan kebijakan pengadaan barang perseroan. Pada Matahari Department Store Tbk (LPPF) dan Multipolar Tbk (MLPL), perseroan melakukan seleksi vendor atau pemasok berdasarkan kebijakan procurement internal yang dikelola melalui Divisi Procurement.

Sedangkan pada kedua perusahaan lainnya yaitu Matahari Putra Prima Tbk (MPPA) dan Siloam International Hospitals Tbk (SILO) belum memiliki kebijakan yang secara khusus mengatur mengenai seleksi dan peningkatan kemampuan pemasok atau vendor. Namun pada masing-masing perusahaan tersebut memiliki tim pengadaan yang bertanggung jawab untuk mengambil keputusan mengenai seleksi vendor yang dibutuhkan oleh perusahaan. Selanjutnya, Dalam menjalin kerjasama dengan pemasok atau vendor, Matahari Department Store Tbk (LPPF) dan Matahari Putra Prima Tbk (MPPA) sama-sama menerapkan standar yang tinggi dalam etika dan perilaku bisnis sehingga apabila pemasok terbukti tidak memenuhi kewajibannya maka perseroan akan mengambil tindakan tegas untuk memutus hubungan kerjasama dengan pemasok.

Dengan demikian dapat disimpulkan bahwa pemasok atau vendor merupakan salah satu kelompok stakeholder yang cukup berperan penting terhadap keberlangsungan perusahaan, dikarenakan dengan adanya pemasok dapat membantu memenuhi kebutuhan perusahaan. Selain itu, perusahaan juga selalu 
berusaha menjaga hubungan dengan pemasok atau pelanggan dalam pelaksanaan CSR yang dapat berdampak terhadap pemasok atau pelanggan tersebut. Dapat diketahui juga bahwa pada kedua belas perusahaan yang diteliti, sebagian besar perusahaan memiliki kebijakan yang mengatur tentang seleksi dan peningkatan kemampuan pemasok atau vendor. Kebijakan tersebut juga telah diungkapkan dalam Laporan Tahunan perusahaan.

\section{Pelanggan}

Customer atau yang dikenal dengan pelanggan adalah orang yang membeli barang atau produk yang telah dihasilkan atau diproduksi oleh suatu perusahaan. Orang tersebut tidak hanya membeli barang sekali saja, namun membeli barang berulang-ulang kali sehingga bisa dikatakan sebagai pelanggan. Seperti yang sudah dijelaskan dalam teknik analisis pada bagian lembar coding, didalam pokok pelanggan ini terdapat point lainnya yaitu seperti kelompok fokus, panel penasihat perusahaan dan komunitas tertulis. Namun untuk point kelompok fokus dan komunitas tertulis, pada kedua belas perusahaan tidak menjelaskan dalam laporan tahunannya.

Pada kedua belas perusahaan yang diteliti, terdapat dua perusahaan yang tidak menjelaskan mengenai interaksi dengan pelanggannya. Perusahaan tersebut adalah Star Pacific Tbk (LPLI) dan Lippo Securities Tbk (LPPS). Pada perusahaan Gowa Makassar Tourism Development Tbk (GMTD) untuk mewujudkan inisiatif layanan yang baik, maka perseroan menggagas setiap ide yang diberikan dan memberikan harga produk yang terjangkau dan kompetitif. Dengan adanya hal tersebut, dapat menekankan terciptanya nilai tambah bagi pelanggan dan dapat meningkatkan kepuasan konsumen baik sebelum maupun sesudah bertransaksi dengan perseroan. Selain itu, perseroan menyediakan penjualan secara online dan membuat aplikasi Residential Service yang dapat mencatat pertanyaan, keluhan, kritik, dan saran customer. Hal tersebut dilakukan oleh perusahaan agar dapat meningkatkan kenyamanan, kemudahan, kepuasan, dan loyalitas customer terhadap perusahaan. Perseroan juga melakukan pengembangan karyawan baik yang dilakukan secara internal maupun eksternal agar dapat melakukan kegiatan dalam marketing seperti selling skill dengan baik.

Perusahaan Lippo Cikarang Tbk (LPCK) memiliki empat segmen bisnis yaitu residential, industrial, comersial, dan township management service yang terintegrasi dengan baik sehingga dapat memenuhi kebutuhan pelanggannya. Perseroan juga selalu mengutamakan kepuasan pelanggan dengan terus berinovasi dan perseroan juga memastikan bahwa seluruh pelanggannya mampu menikmati produk dan jasa dengan optimal. Dalam meningkatkan kualitas hubungan serta mengetahui tingkat kepuasan para konsumennya, perseroan juga rutin mengadakan acara pertemuan dengan toko-toko besar (tenant) di kawasan industri dan memastikan bahwa sarana komunikasi dengan pelanggan selalu tersedia.

Selain itu dengan memanfaatkan fitur teknologi terkini, perseroan terus berupaya meningkatkan kualitas produk dan jasa serta pelayanan yang diberikan kepada pelanggan. Perseroan juga akan mengembangkan beberapa program yang salah satunya yaitu Mobile Apps Lippo Cikarang. Selain itu, perseroan juga akan mengembangkan fitur Customer Loyalty Point Rewards yang memberikan sistem poin kepada loyal customers dari Lippo Cikarang dan poin tersebut dapat ditukarkan dengan hadiah menarik. Perseroan juga membuat strategi pemasaran yang dapat dilakukan oleh perusahaan dalam memasarkan produk atau layanannya kepada pelanggan. Melalui customer understanding Perusahaan Lippo General Insurance Tbk (LPGI) dapat mengidentifikasi pelanggan yang menjadi fokus perseroan dan memahami karakteristiknya. Untuk meningkatkan kepuasan pelanggannya, perseroan terus meningkatkan kualitas produk dan layanan yang diberikan. Selain itu perseroan juga berkomitmen untuk selalu menghadirkan layanan terbaik dan memberikan kenyamanan dan perlindungan bagi pelanggan dengan bentuk Pusat Pengaduan Konsumen (Customer Care), Program Engagement Konsumen, dan Program Peningkatan Layanan. Seiring dengan perkembangan teknologi, perseroan mengembangkan aplikasi berbasis mobile untuk memberikan kemudahan akses dan layanan yang lebih baik bagi pelanggan.

Pada perusahaan Lippo Karawaci Tbk (LPKR) menerapkan Enterprise Resource Planning (ERP) yang bertujuan untuk mempermudah pelanggan dalam melakukan akses atas layanan dan produk yang tersedia. Perseroan juga melakukan kegiatan-kegiatan yang melibatkan para pelanggan dan tenant yaitu seperti sebanyak 25 mal jaringan Lippo Karawaci mengadakan tenant gathering dan sebanyak 12 mal jaringan Lippo Karawaci mengadakan program belanja. Selain itu, manajer penjualan dan manajer pemasaran perseroan akan bekerja sama dalam menentukan rencana iklan dan penjualan untuk pengembangan proyek tertentu, melakukan riset pasar untuk menyusun strategi penjualan dan penetapan harga, dan mengumpulkan data dan tanggapan pelanggan.

“...dalam setiap kegiatan usaha Perseroan baik pada sisi back office dengan penerapan Enterprise Resource Planning (ERP) maupun pada personil garda depan untuk mempermudah pelanggan kami melakukan akses atas layanan dan produk yang tersedia." (Laporan Tahunan Perusahaan Lippo Karawaci Tbk (LPKR) 2018, hal. 35) 
Pada perusahaan Matahari Department Store Tbk (LPPF) dalam meningkatkan fokusnya pada pelanggan, perseroan akan meningkatkan penawaran produk dan terus mengembangkan platform omnichannel serta menumbuhkan basis pelanggan loyalitas perseroan. Matahari Department Store juga akan melakukan segala upaya untuk melindungi keselamatan, mempertimbangkan keamanan dan kenyamanan setiap pelanggannya. Selain itu, perseroan juga mengembangkan aplikasi seluler matahari melalui MATAHARI.com untuk dapat mempermudah pelanggan dalam berbelanja secara online. Pelanggan juga dapat mendaftarkan keluhan, membuat saran, meminta informasi atau memberikan masukan lain tentang produk dan layanan Matahari melalui layanan pelanggan di dalam gerai Matahari selama waktu operasional gerai atau melalui Layanan Call Centre Halo Matahari. Dalam memperkuat keterlibatan perseroan dengan para pelanggan, perseroan melakukannya melalui program loyalitas Matahari Rewards. Program tersebut adalah alat yang berharga dalam mengelola hubungan dengan pelanggan Matahari.

Perusahaan Multipolar Tbk (MLPL) bersama dengan anak-anak perusahaan terus berinovasi untuk dapat meningkatkan prosedur dan mekanisme keluhan pelanggan sehingga setiap keluhan dapat ditangani dengan baik. Perseroan juga mengimplementasikan kebijakan-kebijakan yang memastikan bahwa kualitas produk dan layanan tetap terjaga sehingga dapat meningkatkan nilai yang ditawarkan kepada konsumen. Kemudian, pada Perusahaan Matahari Putra Prima Tbk (MPPA) dalam memperkuat loyalitas pelanggannya, perseroan bekerjasama dengan OVO. Perseroan juga memanfaatkan teknologi modern untuk dapat berkomunikasi dengan pelanggannya melalui media sosial elektronik. Pelanggan perseroan juga dapat mengajukan keluhan, memberikan umpan balik atau meminta informasi mengenai produk dan layanan melalui layanan pelanggan di dalam gerai-gerai perseroan selama waktu operasional perseroan atau melalui layanan interaksi di beberapa media sosial perseroan dan dapat melalui layanan email perseroan.

"Perseroan memperkuat loyalitas pelanggan melalui kerjasama dengan OVO, salah satu operator fintech terkemuka di Indonesia dengan pertumbuhan yang sangat pesat." (Laporan Tahunan Matahari Putra Prima Tbk (MPPA) 2018, hal. 44)

Untuk Bank Nationalnobu Tbk (NOBU) berkomitmen untuk menggunakan Customer Centric Culture dalam hal layanan pelanggan. Layanan perbankan yang diberikan kepada nasabah yaitu pembukaan rekening, setor tunai, penarikan tunai, pemindahan buku, pembayaran (biller), transfer ke bank lain dan top up saldo Nobu e-Pay (uang elektronik). Untuk memastikan bahwa setiap keluhan pelanggan dapat disampaikan dengan mudah dan dapat ditangani dengan baik, maka perseroan menggunakan mekanisme call center di bawah unit yang membidangi service quality. Selain itu, perseroan juga membuat program pemasaran yang dapat memberikan berbagai manfaat menarik bagi nasabah baik hadiah langsung maupun keuntungan menarik lainnya.

Selanjutnya, Siloam International Hospital Tbk (SILO) meluncurkan sistem Enterprise Resource Planning (ERP) dan sistem informasi rumah sakit yang dapat memberikan layanan yang baik bagi pelanggan. Perseroan juga telah menetapkan Center of Excellence di setiap rumah sakit. Center of Excellence perseroan berbeda dengan penyedia pelayanan kesehatan lainnya karena dokter spesialis dan perawat berkualitas akan memberikan perawatan terbaik kepada pasien yang hadir di Center of Excellence. Setiap Center of Excellence menyediakan pelayanan komprehensif dalam menjalankan perawatan, melakukan skrining, diagnosis, manajemen klinis, rehabilitasi dan edukasi pendidikan. Perseroan juga melakukan berbagai kegiatan pemasaran yang bertujuan untuk mempertahankan basis pelanggan saat ini dan memperkuat hubungan dengan pelanggan.

"Pada tahun 2018 Siloam meluncurkan sistem Enterprise Resource Planning (ERP) dan sistem informasi rumah sakit. Kami berhasil memigrasi seluruh sistem rumah sakit kami ke satu sistem kantor belakang dan kantor depan utama. Implementasi sistem ini sudah mengarah kepada sistem layanan pelanggan yang lebih baik serta tingkat efisiensi yang lebih tinggi atas rantai pemasok dan manajemen inventaris kami." (Laporan Tahunan Siloam International Hospitals Tbk (SILO) 2018, hal. 22)

Dari kedua belas perusahaan yang diteliti, dapat disimpulkan bahwa kedua belas perusahaan akan selalu menjaga dan memperkuat hubungannya dengan pelanggan. Dalam hal CSR yang dilakukan oleh perusahaan kepada para pelanggannya, perseroan akan melakukan tanggung jawab terhadap produk dan layanan yang diberikan oleh perusahaan. Perusahaan juga akan melakukan berbagai hal agar dapat memberikan produk dan jasa serta layanan yang terbaik bagi pelanggannya supaya kepuasan konsumen dapat meningkat. Dengan begitu, pelanggan akan merasa aman dan nyaman jika bertransaksi dengan perseroan.

\section{Tenaga Kerja}

Tenaga kerja atau yang biasa disebut pekerja atau karyawan adalah orang yang bekerja pada suatu lembaga baik di kantor maupun perusahaan yang menggunakan tenaga atau kemampuannya untuk 
mendapatkan pendapatan berupa gaji atau upah. Sama halnya dengan yang telah dijelaskan dalam teknik analisis bahwa dalam point tenaga kerja ini terdapat dua point lainnya juga seperti Manajemen atau Struktur Serikat Buruh dan Perjanjian Perundingan Kolektif.

Perusahaan Gowa Makassar Tourism Development Tbk (GMTD) menetapkan standar dalam proses perekrutan karyawan dan melakukan program-program pengembangan karyawan melalui pelatihan yang dapat meningkatkan kualitas dan kompetensi karyawan. Dalam melakukan evaluasi terhadap kinerja karyawan, perseroan menggunakan metode self-assessment. Perseroan tidak memiliki Serikat Pekerja, akan tetapi perseroan senantiasa membangun hubungan yang harmonis dan saling menguntungkan bagi para karyawan. Divisi Sumber Daya Manusia perusahaan juga memiliki sarana untuk menangani keluhan karyawan dan persengketaan yang terjadi. Selain itu, perseroan menyediakan program pasca kerja berupa DPLK (Dana Pensiun Lembaga Keuangan) bagi karyawan yang memasuki masa pensiun.

"Meski tidak memiliki Serikat Pekerja, Perseroan senantiasa membangun hubungan yang harmonis dan saling menguntungkan dengan para karyawan." (Laporan Tahunan Perusahaan Gowa Makassar Tourism Development Tbk (GMTD) 2018, hal. 125)

Pada Perusahaan Lippo Cikarang Tbk (LPCK) untuk meningkatkan kompetensi karyawannya, perseroan menyelenggarakan berbagai kegiatan seperti pelatihan dan pengembangan kompetensi baik di bidang hard skill maupun soft skill, perseroan juga melakukan Project Trainee dan Management Trainee, dan perseroan memberikan kesempatan pada karyawan terpilih untuk mengikuti program studi S2. Selain itu, Perseroan menerapkan kebijakan ketenagakerjaan sesuai dengan peraturan perundangan yang berlaku, kebijakan K3L dalam hal penerapan aspek kesehatan dan keselamatan kerja, serta memberlakukan Kode Etik Perusahaan dalam hal pedoman tingkah laku dan peraturan perusahaan bagi seluruh karyawan di dalam perseroan. Bagi karyawan yang melakukan pelanggaran, maka akan dikenakan sanksi melalui surat peringatan tertulis hingga pemutusan hubungan kerja.

Dalam melakukan penilaian kinerja karyawan, perseroan menggunakan metode self-assessment dan kemudian akan dievaluasi lebih oleh atasan karyawan yang bersangkutan. Perusahaan juga mengikutsertakan seluruh karyawan dalam Jaminan Kecelakan Kerja (BPJS Ketenagakerjaan), BPJS Kesehatan, Dana Pensiun, dan Asuransi Kesehatan Swasta. Namun, perseroan belum memiliki kebijakan mengenai pemberian insentif jangka panjang kepada Direksi dan karyawan.

"Kode Etik Perseroan berlaku secara universal bagi seluruh karyawan Perseroan di seluruh level organisasi. Pokok-pokok utama sebagaimana tercantum dalam Kode Etik Perusahaan adalah untuk: Integritas dan pertentangan kepentingan; Kepatuhan terhadap peraturan atau perundang-undangan (internal dan eksternal); Pertanggungjawaban sebagai karyawan; Menghargai sesama karyawan dan pedoman dalam berhubungan karyawan lain, perusahaan, pelanggan, pihak ketiga seperti pemasok/vendor/konsultan, pesaing, dan lainnya." (Laporan Tahunan Perusahaan Lippo Cikarang Tbk (LPCK) 2018, hal. 233-234)

Proses rekrutmen karyawan yang dilakukan oleh Perusahaan_Lippo General Insurance Tbk (LPGI) dilaksanakan melalui jalur internal bagi posisi manajemen puncak dan jalur eksternal bagi program fresh graduate melalui Officer Development Program (ODP) dan promosi. Perseroan memberikan atau mengikutsertakan seluruh karyawan dalam berbagai program pendidikan, pelatihan, seminar, workshop, dan conference yang diselenggarakan secara internal maupun eksternal yang bertujuan untuk meningkatkan keahlian dan kompetensi karyawan.

Pada perseroan terdapat Kode Etik yang mengatur karyawan dan Kebijakan yang menjadi dasar untuk digunakan karyawan tertuang dalam bidang Etika dan Tanggung Jawab Profesi. Perseroan juga memiliki sarana pengungkapan pelanggaran karyawan dalam sistem portal internal perseroan dan dapat diakses dengan menggunakan user id masing-masing karyawan. Bagi karyawan yang ketahuan melakukan pelanggaran maka akan dikenakan sanksi dan mengacu pada peraturan perusahaan. Perseroan juga belum memiliki kebijakan pemberian insentif jangka panjang kepada Direksi dan karyawan.

"Ketentuan yang termuat dalam Etika dan Tanggung Jawab Profesi telah diatur oleh Perseroan dalam peraturan tersendiri tetapi tetap menjadi kesatuan dan bagian yang tidak terpisahkan dari Peraturan Perusahaan. Ketentuan tersebut diatur dalam Pasal 21 Bab VII Peraturan Perusahaan tentang Etika dan Tanggung Jawab Profesi dan memuat tentang petunjuk akhlak dan etika dalam bertindak dan berperilaku para insan Perseroan agar bersama-sama dapat mencapai visi, misi, serta tujuan Perseroan." (Laporan Tahunan Lippo General Insurance Tbk (LPGI) 2018, hal. 168)

Program rekrutmen pada perusahaan Lippo Karawaci Tbk (LPKR) dilakukan oleh calon karyawan dengan registrasi di lowongan pekerjaan sesuai dengan kerjaan yang diinginkan. Selain program rekrutmen, perseroan juga melakukan promosi dan mutasi sesuai dengan evaluasi kinerja karyawan. Perseroan juga menyelenggarakan dan memfasilitasi berbagai program pelatihan dan pengembangan kompetensi karyawan yang dilakukan secara berkala pada setiap tahunnya. Salah satu program yang dimaksud adalah Program Orientasi Karyawan Baru. Selain itu, perseroan juga memberikan program 
beasiswa untuk para karyawan yang berprestasi. Dalam melakukan penilaian kinerja karyawan, perseroan menerapkan sistem penilaian Key Performance Indicator (KPI) supaya karyawan mampu memaksimalkan potensi dan kinerjanya masing-masing. Perseroan juga menetapkan kebijakan Kode Etik di dalam perusahaan supaya seluruh karyawan dan Manajemen dapat menjadikan pedoman dalam bertingkah laku.

Pada perusahaan Star Pacific Tbk (LPLI) dalam meningkatkan kemampuan dan pengetahuan karyawannya, perseroan mengikutsertakan karyawannya pada pelatihan-pelatihan dan seminar-seminar sesuai dengan kebutuhan perseroan dan bidang pekerjaan karyawan. Selain itu, perseroan juga memberlakukan kebijakan Kode etik supaya dapat dipatuhi oleh seluruh karyawan dan Direksi perusahaan. Dalam memenuhi kesejahteraan karyawannya, perseroan memberikan gaji dan upah yang sejalan dengan laju inflasi dan diatas standar gaji minimum dan Upah Minimum Regional (UMR) serta pemberian tunjangan-tunjangan lainnya sesuai dengan ketentuan-ketentuan Pemerintah. Perseroan juga belum memiliki kebijakan pemberian insentif jangka panjang kepada Direksi dan karyawan serta karyawan pada perseroan tidak memiliki Serikat Pekerja.

Matahari Department Store Tbk (LPPF) menetapkan kebijakan rekrutmen dalam mempekerjakan karyawan dan memastikan bahwa kebijakan tersebut sesuai dengan peraturan yang berlaku bagi perusahaan. Selain kebijakan perekrutan, perseroan juga memiliki Kode Etik yang berlaku untuk semua karyawan dan anggota organisasi termasuk Tim Manajemen, Direksi, dan Dewan Komisaris. Perseroan terus berinvestasi dalam mengembangkan keterampilan dan potensi karyawannya dengan memberikan reward yang kompetitif baik melalui gaji maupun peluang. Selain itu, perseroan juga menawarkan berbagai program pelatihan dan pengembangan kompetensi karyawan berupa program pelatihan umum seperti program orientasi karyawan baru serta pelatihan soft skill dan program pengembangan kompetensi Staf.

Pada perusahaan Lippo Securities Tbk (LPPS) untuk meningkatkan sumber daya manusianya, perseroan mengirimkan karyawan-karyawannya untuk mengikuti program pendidikan berupa training atau pelatihan, seminar, dan lokarya di dalam negeri. Dalam perusahaan Lippo Securities ini pedoman berperilaku disosialisasikan kepada seluruh karyawan. Selain itu, perusahaan juga mempertahankan budaya kerja beretika yang dapat menjaga agar tanggung jawab dan hasil terbaik yang diperoleh dari setiap karyawannya. Perusahaan juga melakukan pendekatan berorientasi dalam mengukur kinerja untuk dapat mengetahui, mengerti dan mendorong kemampuan karyawannya. Perusahaan juga belum memiliki kebijakan mengenai pemberian insentif jangka panjang kepada Direksi dan karyawan.

Perusahaan Multipolar Tbk (MLPL) merekrut karyawannya dengan cara memasang iklan di media konvensional dan media online serta kegiatan rekrutmen langsung di kampus-kampus. Perseroan melaksanakan penilaian kinerja karyawan secara berkala dengan berdasarkan indikator kinerja dan perseroan juga memberikan kesempatan bagi karyawannya untuk mengikuti serangkaian pelatihan seperti lokarya, seminar, dan pelatihan yang dipimpin langsung oleh instruktur dan pelatih kerja profesional. Perusahaan Multipolar ini menetapkan pedoman perilaku yang berlaku bagi seluruh anggota Direksi dan Dewan Komisaris beserta seluruh karyawan dan perseroan akan memberikan penghargaan berupa insentif dan paket menarik kepada karyawannya.

Proses perekrutan yang dilakukan oleh perusahaan Multipolar Technology Tbk (MLPT) cukup ketat karena menerapkan sistem terpadu untuk seleksi, perekrutan, pelibatan dan pelatihan karyawan akan dilakukan secara hati-hati berdasarkan standar yang telah ditetapkan. Perseroan juga akan mendorong dan memotivasi karyawannya untuk terus mengembangkan dan mempertahankan daya saingnya dan karyawan akan mengikuti program pelatihan baik yang bersertifikasi maupun non-sertifikasi seperti pelatihan publik yang terdiri dari seminar, sertifikasi profesional dan pelatihan internal seperti pengembangan kompetensi non-teknis yang diselenggarakan oleh perusahaan. Perusahaan juga menyediakan program beasiswa untuk kuliah pascasarjana atau program pendidikan formal bagi karyawan yang memiliki kemampuan diatas rata-rata dan memenuhi syarat.

Pada perusahaan Matahari Putra Prima Tbk (MPPA) kode etik perusahaan juga berlaku secara merata untuk semua karyawan dan anggota organisasi termasuk Dewan Komisaris, Direksi dan Tim Manajemen. Bagi karyawan yang baru bergabung, perseroan akan memberikan pelatihan dan kepada karyawan yang telah bergabung akan diberikan kesempatan untuk mengembangkan karirnya dengan mengikuti beberapa program pelatihan pengembangan, peningkatan keahlian dan peningkatan kemampuan kepemimpinan. Perseroan akan memberikan tanggung jawabnya kepada karyawan dengan menyediakan lingkungan kerja yang inklusif, adil dan bermanfaat sesuai dengan undang-undang dan peraturan terkait ketenagakerjaan. Selain itu, perseroan menyediakan tunjangan kesehatan dan tunjangan pensiun melalui BPJS, asuransi jiwa, tunjangan kehamilan, dan program kepemilikan kendaraan untuk karyawan di level tertentu. Perseroan juga akan memberikan pesangon dan penghargaan atas layanan bagi karyawan yang mencapai usia pensiun 55 tahun. 
Matahari Putra Prima belum memiliki insentif jangka panjang untuk Direksi dan Karyawannya. Didalam perusahaan ini memiliki Serikat Pekerja yang sama dengan perusahaan Matahari Department Store yaitu Ikatan Karyawan Matahari (IKM) dan terdapat satu lembaga lagi yaitu Lembaga Bipartit (LKS Bipartit). IKM dan LKS Bipartit tersebut merupakan forum komunikasi antara karyawan dan pihak manajemen. Selain itu perseroan juga bekerja sama dengan Koperasi Karyawan yang bertujuan untuk meningkatkan kesejahteraan karyawan. Ikatan Karyawan Matahari (IKM), Forum Bipartit dan Koperasi Karyawan menyusun suatu perjanjian yang kooperatif dan positif antara perseroan dengan karyawannya.

"Tanggung jawab Perseroan terhadap karyawan dengan menegakkan semua undang-undang dan peraturan terkait ketenagakerjaan yang relevan di tingkat lokal dan nasional, dan dengan menyediakan lingkungan kerja yang inklusif, adil dan bermanfaat..." (Laporan Tahunan Matahari Putra Prima (MPPA) 2018, hal. 130)

Untuk Bank Nationalnobu Tbk (NOBU) proses seleksi dan rekrutmen karyawan dilakukan melalui sumber internal dan sumber eksternal. Untuk sumber internal ada beberapa program pengembangan karir yang ditujukan untuk karyawan yang memiliki penilaian kinerja yang memuaskan. Sedangkan untuk sumber eksternal dilakukan untuk fresh graduate maupun experience hire. Untuk semua kandidat yang didapatkan oleh perusahaan akan tetap melalui proses seleksi dengan standar yang sesuai dengan ketentuan perseroan. Perseroan juga menetapkan kode etik yang diberlakukan kepada seluruh karyawan perusahaan. Selain pemberian gaji setiap bulan dan Tunjangan Hari Raya (THR) setiap tahun, kesejahteraan para pekerja perseroan diupayakan melalui program asuransi kesehatan, bantuan pemeliharaan kesehatan lainnya, bantuan persalinan atau keguguran, bantuan kedukaan bagi karyawan dan keluarga inti pekerja, pinjaman lunak dalam kondisi darurat dan perseroan mendaftarkan seluruh pekerja dalam kepesertaan BPJS Kesehatan dan BPJS Ketenagakerjaan.

Selanjutnya, Siloam International Hospitals Tbk (SILO) menerapkan standar yang tinggi dan kepatuhan terhadap klinis yang ketat mengenai perekrutan tenaga ahli kesehatan dan penyimpanan karyawan. Metode rekrutmen domestik dan internasional digunakan untuk memenuhi kebutuhan untuk mengisi berbagai posisi penting seperti dokter, perawat, teknisi medis, administrator, dan karyawan pendukung. Siloam Hospital juga mengembangkan pedoman tata cara berperilaku sebagai standar perilaku bagi seluruh karyawan. Perusahaan juga melakukan beberapa program pelatihan dan pengembangan mendasar seperti program beasiswa bagi talenta pekerja muda untuk menjalani pelatihan keperawatan. Siloam Hospital juga memberikan penghargaan kepada karyawan berupa bonus kinerja, sistem penyesuaian gaji tahunan, Tunjangan Hari Raya dan asuransi kesehatan keluarga, penghargaan bagi karyawan dengan masa kerja yang lama, sertifikat atas prestasi yang luar biasa, program pelatihan dan sistem promosi berbasis prestasi, liburan dan berkumpul bersama keluarga. Perusahaan juga belum memiliki kebijakan pemberian insentif jangka panjang kepada Direksi dan karyawannya. Standar tinggi yang di maksud dalam perekrutan tenaga ahli kesehatan yaitu:

"Semua ahli kesehatan pada Siloam Hospitals harus sepenuhnya memenuhi syarat dan mematuhi standar medis tertinggi. Untuk mencapai hal ini, kami berkomitmen untuk menilai dan memverifikasi semua ahli kesehatan yang mempunyai sertifikasi pada saat perekrutan, dan diuji ulang setiap 3 tahun..." (Laporan Tahunan Siloam International Hospitals Tbk (SILO) 2018, hal. 148)

Dapat disimpulkan dari kedua belas perusahaan yang telah diteliti diketahui bahwa perseroan menyadari peran sumber daya manusia yang sangat berpengaruh dalam mendukung pertumbuhan bisnis dan pengembangan organisasi dari perseroan tersebut. Sehingga setiap perusahaan akan terus mengembangkan karyawannya dengan melakukan berbagai program yang bisa membantu meningkatkan kualitas dan kompetensi karyawan. Dalam hal CSR yang perusahaan lakukan terhadap karyawannya, perusahaan akan selalu menerapkan K3 yaitu Ketenagakerjaan, Kesehatan dan Keselamatan Kerja yang ditujukan untuk seluruh karyawannya.

\section{Kelompok Stakeholder Lainnya}

Dalam kelompok stakeholder lainnya ini terdapat panel komunitas karena dalam panel komunitas ini menjelaskan mengenai komunikasi yang perusahaan berikan kepada para pemegang saham atau investor, calon investor, Pemerintah dan Masyarakat umum. Dari kedua belas perusahaan yang dianalisis, terdapat empat perusahaan yaitu Lippo General Insurance Tbk (LPGI), Star Pacific Tbk (LPLI), Lippo Securities Tbk (LPPS), dan Siloam International Hospitals Tbk (SILO) yang memiliki kebijakan komunikasi dengan para pemegang saham atau investor. Kempat perseroan tersebut melakukan komunikasi kepada para pemegang saham atau investor melalui RUPS, paparan publik (Public Expose) dan website perusahaan. Namun pada Siloam International Hospitals Tbk (SILO) selain melalui beberapa cara di atas, perseroan juga melakukan Non-deal Roadshow, One on One Meeting, Conference dan Investor Summit.

Pengelolaan seluruh kanal komunikasi pada perusahaan Gowa Makassar Tourism Development Tbk (GMTD) dilakukan semakin baik di tiap tahunnya sehingga dapat mencerminkan itikad yang kuat dari 
perseroan dalam melaksanakan tanggung jawabnya terhadap produk dan layanan yang diberikan. Pada perusahaan Lippo Cikarang Tbk (LPCK) melakukan pengaturan mengenai metode dan proses pemberian informasi atau berita dan prosedur komunikasi yang diberikan perusahaan kepada Public Relations dan Investor Relations. Perusahaan juga berusaha menjaga hubungan baik dengan instansi pemerintah, pasar modal dan asosiasi yang terkait dengan perusahaan.

Pada perusahaan Lippo Karawaci Tbk (LPKR), perseroan selalu memastikan agar kebijakan dan petunjuk Direksi dapat dikomunikasikan secara tepat dan baik kepada pihak-pihak terkait di dalam maupun diluar perusahaan termasuk para stakeholders. Sedangkan pada Matahari Department Store Tbk (LPPF) selalu menjaga komunikasi yang rutin dan terbuka dengan para stakeholder eksternal serta menyediakan sarana untuk mengungkapkan informasi secara cepat kepada masyarakat mengenai kinerja dan operasi perseroan. Dalam mengungkapkan semua kebijakan komunikasi, perusahaan Multipolar Tbk (MLPL) menyediakan materi presentasi dan laporan keuangan melalui situs web perusahaan untuk memberikan kesempatan dan akses yang sama kepada seluruh pemegang saham atau investor.

Perusahaan Multipolar Technology Tbk (MLPT) membangun komunikasi yang aktif dan menjalin hubungan transparan dengan berbagai pihak serta mempertahankan komunikasi terbuka antara pihak internal dan eksternal perusahaan. Perseroan juga menjalin hubungan baik dengan komunitas bisnis tempat perseroan beroperasi dan memfasilitasi pertukaran informasi dengan para stakeholders perusahaan. Pada perusahaan Matahari Putra Prima Tbk (MPPA) memiliki sekretaris perusahaan yang bertindak sebagai penghubung dalam menjalin komunikasi dengan OJK, BEI dan lembaga regulator lainnya, serta masyarakat umum, calon investor dan pemegang saham. Selain itu, perseroan juga memiliki kebijakan komunikasi kepada investor melalui divisi Investor Relation dalam bentuk Non deal Roadshow, siaran pers, rapat, ekspos publik dan konferensi. Untuk Bank Nationalnobu Tbk (NOBU) memiliki sekretaris perusahaan yang berperan sebagai penghubung komunikasi agar berjalan efektif dan memastikan tersedianya informasi untuk berbagai pihak dan berperan juga sebagai penghubung utama Bank dengan OJK dan publik.

Berdasarkan analisis diatas dapat disimpulkan bahwa pemasok, pelanggan dan kelompok stakeholder lainnya yaitu calon investor, Pemerintah, masyarakat umum dan lembaga regulator seperti OJK dan BEI merupakan stakeholders eksternal dari perusahaan dikarenakan berada di luar lingkungan organisasi. Sedangkan tenaga kerja dan kelompok stakeholder lainnya yaitu pemegang saham atau investor termasuk dalam stakeholder internal perusahaan dikarenakan berada di dalam lingkungan organisasi. Untuk berhubungan dengan kelompok stakeholder peran utama ada di public relations, investor relations, dan corporate secretary. Selain itu, sasaran komunikasi yang digunakan berbasis transparansi informasi.

\section{Simpulan dan saran}

Rumusan masalah dalam penelitian ini adalah bagaimana penyajian pokok stakeholder engagement dalam pengungkapan CSR. Masalah penelitian tersebut dijawab melalui analisis isi pengungkapan pokok stakeholder engagement yang telah dilakukan pada dua belas perusahaan afiliasi Lippo Group yang telah diteliti. Analisis isi dilakukan dengan melihat pokok stakeholder engagement pada laporan tahunan perusahaan yang diteliti yang didasarkan pada Standar GRI 102. Berdasarkan hasil analisis dapat disimpulkan bahwa pokok-pokok stakeholder engagement yaitu Pemasok, Pelanggan, Tenaga Kerja dan Kelompok stakeholder lainnya yang telah diatur dalam standar GRI 102, secara keseluruhan telah diungkapkan dalam laporan tahunan perusahaan yang diteliti.

Pokok-pokok tersebut diketahui bahwa cukup berperan penting dalam keberlangsungan suatu perusahaan dan dalam pengungkapan CSR. Hal ini sejalan dengan hasil penelitian yang dilakukan oleh Rowley \& Berman (2000), yang menyatakan bahwa stakeholder berhubungan terhadap pengungkapan yang dilakukan oleh perusahaan. Lindawati \& Puspita (2015) menyatakan bahwa pengungkapan CSR yang dilakukan oleh perusahaan akan membuat stakeholder memberikan dukungan penuh terhadap perusahaan atas aktivitas bisnis yang dilakukan. Pada analisis isi penelitian ini pokok-pokok stakeholder engagement seperti pelanggan dan tenaga kerja akan menjaga hubungan dengan perusahaan dan memberikan dukungannya atas aktivitas bisnis perusahaan apabila perusahaan juga memberikan dan mengungkapkan tanggung jawabnya tersebut kepada konsumen dan tenaga kerja perusahaan.

Pokok stakeholder engagement yang pertama yaitu pemasok diungkapkan oleh seluruh perusahaan yang diteliti, dan secara keseluruhan dalam menyeleksi pemasok atau vendor mengacu pada pelaksanaan GCG sesuai dengan SEOJK no 32/POJK.04/2015 pada aspek keempat mengenai Partisipasi Pemangku Kepentingan. Sedangkan untuk pokok yang kedua yaitu mengenai pelanggan, diungkapkan oleh sepuluh perusahaan dari kedua belas perusahaan yang diteliti. Pada kesepuluh perusahaan tersebut dalam mengungkapkan interaksinya dengan pelanggan, perseroan akan selalu menjaga dan memperkuat 
hubungannya dengan pelanggan melalui tanggung jawab terhadap produk dan layanan yang diberikan oleh perusahaan. Dalam pokok yang ketiga mengenai tenaga kerja, diungkapkan oleh seluruh perusahaan yang diteliti dengan selalu memberikan keamanan dan kenyamanan kerja melalui penerapan K3 dan pemberian tunjangan-tunjangan. Selain itu, perseroan juga selalu mendukung karyawannya dalam meningkatkan kualitas dan kompetensi karyawannya. Pada pokok yang terakhir yaitu kelompok stakeholder lainnya, diungkapkan oleh seluruh perusahaan melalui komunikasi yang perseroan berikan kepada para pemegang saham atau investor, calon investor, Pemerintah dan Masyarakat umum.

Hasil dari penelitian ini memberikan kontribusi empiris yang membahas secara spesifik mengenai keterlibatan stakeholder terhadap praktik pengungkapan CSR pada perusahaan afiliasi Lippo Group, yang belum banyak ditemukan pada penelitian-penelitian sebelumnya. Keterbatasan penelitian ini adalah data yang digunakan hanya satu tahun sehingga hal ini menyebabkan perkembangan atau perubahan yang belum bisa dianalisis dari tahun ke tahun. Selain itu, terbatasnya penelitian pendahulu mengenai stakeholder engagement. Penelitian pendahulu umumnya banyak yang menggunakan pendekatan kuantitatif dari pada pendekatan kualitatif. Saran untuk penelitian yang akan datang mengenai stakeholder engagement sebagai praktik pengungkapan CSR, dapat menggunakan perusahaan afiliasi lainnya atau perusahan dengan jenis industri lainnya. Kemudian, penelitian selanjutnya sebaiknya dapat menggunakan data yang tidak hanya diambil dalam waktu satu tahun sehingga dapat dilihat perubahan atau perkembangan dari tahun ke tahun.

\section{Daftar Rujukan}

Alexander, H. B. (2018). Kondisi meikarta terkini. Retrieved from https://properti.kompas.com/read/2018/10/21/125558721/kondisi-meikarta-terkini?page=all

Andriof, J., Waddock, S., Husted, B., \& Rahman, Sandra S. (2017). Unfolding stakeholder thinking. Unfolding Stakeholder Thinking (Vol. 1). https://doi.org/10.4324/9781351281881

Certo, S. C., \& Certo, S. T. (2006). Modern management concepts and skills. Production. Retrieved from https://www.academia.edu/28377479/MODERN_MANAGEMENT - SAMUEL_C.CERTO and.pdf

Dahlsrud, A. (2008). How corporate social responsibility is defined: An analysis of 37 definitions. Corporate Social Responsibility and Environmental Management, 15(1), 1-13. https://doi.org/10.1002/csr.132

Deegan. (2002). Financial accounting theory Chapter 8 unregulated corporate reporting decisions: Considerations of system-oriented theories. New York: McGraw-Hill Education (UK) Limited an imprint of The McGraw-Hill Companies, Inc.

Dickinson-Delaporte, S., Beverland, M., \& Lindgreen, A. (2010). Building corporate reputation with stakeholders: Exploring the role of message ambiguity for social marketers. European Journal of Marketing, 44(11), 1856-1874. https://doi.org/10.1108/03090561011079918

Dorimulu, P. (2016). Lippo group, 15 perusahaan tercatat di ursa dan pekerjakan 10.000 karyawan. Investor Daily. Retrieved from https://id.beritasatu.com/home/lippo-group-15-perusahaantercatat-di-bursa-dan-pekerjakan-100000-karyawan/150905

Eriyanto. (2011). Analisis isi: Pengantar metodologi untuk penelitian ilmu komunikasi dan ilmu-ilmu sosial lainnya (pertama). PT Fajar Interpratama Mandiri.

Global Reporting Initiative. (2016a). Gri 101: landasan 2016.

Global Reporting Initiative. (2016b). Gri 102: pengungkapan umum 2016102.

Lamudi. (2019). Begini kondisi terakhir proyek apartemen meikarta 2019. Retrieved from https://www.lamudi.co.id/journal/kondisi-terkini-proyek-apartemen-meikarta/

Lindawati, A. S. L., \& Puspita, M. E. (2015). Corporate social responsibility: Implikasi stakeholder dan legitimacy gap dalam peningkatan kinerja perusahaan. Jurnal Akuntansi Multiparadigma, 6(1), 157174. https://doi.org/10.18202/jamal.2015.04.6013 
Lindgreen, A., Swaen, V., \& Johnston, W. J. (2009). Corporate social responsibility: An empirical investigation of U.S. organizations. Journal of Business Ethics, 85(SUPPL. 2), 303-323. https://doi.org/10.1007/s10551-008-9738-8

Marnelly, T. R. (2012). Corporate social responsibility (CSR): Tinjauan teori dan praktek di Indonesia. Jurnal Aplikasi Bisnis, 2(2), 49-59.

Mishra, S., \& Suar, D. (2010). Does corporate social responsibility influence firm performance of Indian companies? Journal of Business Ethics (Vol. 95). https://doi.org/10.1007/s10551-010-0441-1

Rowley, T., \& Berman, S. (2000). A Brand New Brand of Corporate Social Performance. Business \& Society, 39(4), 397-418. https://doi.org/10.1177/000765030003900404

Sofiamira, N. A., \& Asandimitra, N. (2017). Capital expenditure, leverage, good corporate governance, corporate social responsibility: pengaruhnya terhadap nilai perusahaan. Jurnal Ekonomi Dan Bisnis, 20(2), 191-214. https://doi.org/10.24914/jeb.v20i2.691

Tanudjaja, B. B. (2006). Perkembangan corporate social responsibility di Indonesia. Nirmana, 8(2), 92-98. Retrieved from http://puslit2.petra.ac.id/ejournal/index.php/dkv/article/view/17049

Trisnawati, R. (2014). Pengaruh ukuran perusahaan, profitabilitas, leverage, ukuran dewan komisaris dan kepemilikan manjerial terhadap pengungkapan corporate social responsibility (CSR) industri $\begin{array}{lllll}\text { perbankan di } & \text { Indonesia, } & \text { 385-400. } & \text { Retrieved }\end{array}$ https://publikasiilmiah.ums.ac.id/handle/11617/4605

Undang-undang Republik Indonesia (2007). Indonesia: Otoritas Jasa Keuangan. Retrieved from https://www.ojk.go.id/sustainable-finance/id/peraturan/undang-undang/Documents/5. UU-402007 PERSEROAN TERBATAS.pdf

Wineberg, D., \& Rudolph, P. H. (2004). Corporate social responsibility: What every in-house counsel should know (pp. 60-72). 